\title{
The Cry of "Sumampa": A River in Mampong Ashanti in Crisis
}

\author{
Janice Dwomoh Abraham 1*, Isaac Fosu', Daniel Agyapong1, Uchechi Agyemang1, \\ Kwame Nkrumah Hope ${ }^{2}$, John Abraham ${ }^{3}$
}

\footnotetext{
${ }^{1}$ Department of Science Education, College of Agriculture Education, University of Education, Winneba, Ghana ${ }^{2}$ Department of Crop and Soil Sciences Education, College of Agriculture Education, University of Education, Winneba, Ghana ${ }^{3}$ Department of Conservation Biology and Entomology, School of Biological Sciences, College of Agriculture and Natural Sciences, University of Cape Coast, Cape Coast, Ghana

Email: *janice_oduro@yahoo.com
}

How to cite this paper: Abraham, J.D., Fosu, I., Agyapong, D., Agyemang, U., Hope, K.N. and Abraham, J. (2017) The Cry of "Sumampa": A River in Mampong Ashanti in Crisis. Journal of Water Resource and Protection, 9, 40-51.

http://dx.doi.org/10.4236/jwarp.2017.91004

Received: December 4, 2016

Accepted: January 9, 2017

Published: January 12, 2017

Copyright $\odot 2017$ by authors and Scientific Research Publishing Inc. This work is licensed under the Creative Commons Attribution International License (CC BY 4.0).

http://creativecommons.org/licenses/by/4.0/

\begin{abstract}
The Sumampa River in Mampong-Ashanti in Ghana is a very important river that supplies water to the water processing company for treatment for the whole community and its environs. In spite of its importance, the buffer area of the river has been encroached by settlers. Residential houses sited along the river have channeled their waste water into the river and several anthropogenic activities go on along the river. Therefore, this study was conducted to assess the effects of anthropogenic activities on the quality of the river. Water samples were collected from various parts of the river including the source and outflow for physico-chemical and microbial analyses. The results showed that, the water was highly turbid with high total dissolved solids at some points because of intense anthropogenic activities. High turbidity and total dissolved solids greatly influence the microbial load of the water. We therefore recommend that measures are put in place to protect the Sumampa River through the creation of a buffer zone by planting trees along the banks of the river. The trees could help detoxify the run-off water that flows into the river.
\end{abstract}

\section{Keywords}

Anthropogenic Activities, Total Dissolved Solids, Turbidity, Water Quality

\section{Introduction}

Rivers and streams are important sources of freshwater for many homes and communities in Ghana. These rivers passing through or on outskirts of communities serve as the main source of water for the populace who do not have access to portable water [1]. Many other inhabitants of communities which have 
access to portable water make frequent visits to rivers to collect water for domestic use during dry seasons or when there is erratic water supply [2]. The supply of sanitized freshwater is thus an inevitable factor for human economic development [3]. Nevertheless, these rivers and streams can be a major threat to human health as well as the aquatic ecosystem if they are polluted [4] [5] [6]. Unprecedented human growth and rapid economic development has resulted in an increased encroachment on water bodies. Encroachers of water bodies engage in anthropogenic activities that include washing, farming, building roads and houses, mining and clearing of the vegetation along the water. These anthropogenic activities result in waste generation and pollution of the water bodies.

Though rivers and streams are naturally polluted to a certain degree, human interferences are exacerbating the quality of water. These interferences do not only impair the use of water bodies for domestic activities but they also affect the ecological quality of the rivers [7] [8] [9] and their catchment.

Agriculture is one of the major anthropogenic activities found to immensely alter aquatic ecosystems. It has been shown that riparian zones play a key role in stream non-point nutrient and pollution reduction; yet, these zones are replaced by farmlands [10]. This makes the land prone to inundation, washing sediments and chemicals such as fertilizers, fungicides, pesticides and herbicides from the farmlands into river bodies [11] [12]. The nitrates and phosphates in these chemicals invariably cause eutrophication [13] [14], which then affect the aesthetics of the area. The subsequent death and microbial decomposition of the highly dense algal blooms drastically depletes dissolved oxygen (DO), creating a hypoxic or anoxic "dead zone" that lacks sufficient oxygen to support most organisms [15] [16]. This results in an increase in organic loads leading to an increased biochemical oxygen demand (BOD) [2] [17] because their oxidative breakdown requires oxygen. This causes aquatic organisms to become stressed, suffocate and eventually die.

In addition, sediments loads which are washed into streams and rivers increase the total suspended solids (TSS) and total dissolved solids (TDS) causing turbidity of the water. This affect aquatic life by reducing sunlight penetration, damage spawning grounds and also causes toxicity through increase in salinity and changes in the ionic compositions of the water [18] [19]. These suspended solids can also suffocate or expose benthic organisms to hazardous concentration of toxic chemicals leading to their extinction [20] [21]. Pollution of water bodies with these myriads of contaminants has the potential to cause $\mathrm{pH}$ alteration. Most of the metabolic activities of aquatic organisms are $\mathrm{pH}$ dependent; therefore, a highly acidic or alkalinity affects their ability to regulate basic lifesustaining process [19] [22]. Previous studies have shown that, low $\mathrm{pH}$ harms immature fish and also speed up the leaching of heavy metals [13].

Other sources of water pollution in rivers include various industrial discharge, domestic waste; indiscriminate throwing of pathological and commercial wastes, open field defecation, improper disposal of animal waste, animal grazing in water catchments etc. [1] [23] [24]. These human engagements cause microbial po- 
llution by introducing faecal and parasitic larvae into the water via runoff [25]. Faecal coliforms and intestinal enterococci are good indicators for assessing faecal pollution [26]; their presence in water may indicate recent contamination by human sewage or animal droppings [27]. Drinking of such water poses threat to human health because it is known to cause various enteric infections. In addition, local communities along river bodies usually bath and wash their clothes along the river course while others use the banks as dumping sites [23] [28]. Introduction of the detergents and the influx of leachates from the dumping sites find their way into the river water and deteriorate the quality of the water.

Rivers have self-purification capability when they are deluged or adversely affected by human activities; however, at certain pollution levels, purification becomes almost impossible [29]. This means that rivers should be properly managed and constantly checked to prevent the water from deteriorating so as to retain their capacity to supply good quality water [5] [30].

Sumampa is one of the rivers in Mampong-Ashanti that supplies the water processing company in the area with water for treatment and also serve as a source of domestic water for the people in the municipality and its catchment. The river has its source between Mampong-Ashanti and Bonkro, a village close to Nsuta in the Sekyere Central District of Ghana. It flows from its source to the catchment dam of the Ghana Water Company in the Mampong Municipality for treatment and final distributed to homes for various domestic activities such as drinking, washing and cooking. Other inhabitants in the catchment use water from the river for irrigation farming. In the 1980s and early 1990s, the river served as a source of recreation for the people of Mampong-Ashanti. People went to the river to swim on festive occasions such as Christmas, Easter and Independence Day.

The story of the river is different today because there has been so much encroachment on it. The once very big and important river with high water volume all year round has reduced drastically into a stream. A lot of human activities such as building, washing and farming go on along the catchment of the river, thereby exposing the river to a lot of pollutants. The vegetation cover along its banks has been removed at various points. The wetlands along the banks have been used for buildings and fish farming at some points. Therefore, this study was conducted to assess the effects of anthropogenic activities on the quality of the Sumampa River in the Mampong Municipality.

\section{Materials and Methods}

\subsection{Sampling, Handling and Transportation of Water Samples to the Laboratory}

A study was conducted on the Sumampa River from October 2014 to January 2015 in Mampong-Ashanti in the Mampong Municipality of Ghana. For the purpose of the study, the river was stratified into 5 different points starting from a place close to the source along the direction of flow of the water body to a point close to the Mampong water treatment station where the river is dammed 
with other water bodies for treatment. The water sampling points were coded as SU1, SU2, SU3, SU4 and SU5.

At each sampling point, 12 water samples were collected over 12 consecutive weeks resulting in a total of 60 water samples over the study period (Oct. 26, 2014 to Jan. 11, 2015). To keep the samples sterile, the sample collector wore nitrile gloves (Beaucare Medical Ltd, North Yorkshire, UK) and a nose mask (Kwalitex Healthcare Pvt Ltd, Maharashtra, India). Each sample was collected into a sterile $750 \mathrm{ml}$ plastic bottle, labelled and kept on ice for transport to the laboratory for analysis. Sampling was done between the hours of 6:00 and 9:00 each week.

\subsection{Laboratory Analysis Conducted on the Samples}

Physico-chemical analysis conducted on the samples were; measurement of $\mathrm{pH}$ level, determination of turbidity, total dissolved solids (TDS), total hardness and concentration of calcium, magnesium, potassium, sodium and nitrate in the water samples. Microbial load such as total coliform and faecal coliform were also analysed.

The physico-chemical indicators such as $\mathrm{pH}$ and turbidity were measured using $\mathrm{pH}$ meter and turbidity meter respectively. The gravimetric method of analysis was used to determine the total dissolved solids (TDS) in the water samples while the titration method of analysis was used to determine the total hardness. Potassium, sodium, nitrate, calcium and magnesium were also determined using a flame photometer (Keison Products, Chelmsford, Essex, England). All parameters were measures 12 times. For the determination of the TDS, $100 \mathrm{ml}$ of a well-mixed water sample was filtered using a standard Whatman ${ }^{\circledast}$ filter paper (VWR International Ltd, Leicestershire, England). An evaporating dish which has been heated in an oven at $180^{\circ} \mathrm{C}$ for one hour and placed in desiccator was weighed $(x)$ and transferred into a steam bath on a hot plate. The $100 \mathrm{ml}$ filtrate from the filter flask was transferred into the evaporating dish and evaporated to dryness. The evaporating dish residue was transferred to a drying oven where it dried at $180^{\circ} \mathrm{C}$ until a constant weight $(y)$ was attained. The TDS was calculated using Equation (a).

$$
\operatorname{TDS}(\mathrm{mg} / \mathrm{L})=\frac{y-x(\mathrm{mg})}{\text { Sample volume }(\mathrm{l})}
$$

The direct colorimetric titration method was used to determine the total hardness of the water samples [31]. Fifty millilitres $(50 \mathrm{ml})$ of the water sample was pipetted into an evaporating dish after which $0.5 \mathrm{ml}$ of buffer solution was added to it. Six drops of indicator solution was then added and stirred to get the colour of the water turn red. The titration was done by adding the titrating solution slowly to the sample from the burette with constant stirring till there was a colour change from red to blue. The endpoint value from the burette was then taken. The total hardness was calculated using Equation (b).

$$
\mathrm{CaCO}_{3}(\mathrm{mg} / \mathrm{L})=\frac{\text { Titration solution }(\mathrm{ml})}{\text { Sample volume }(\mathrm{ml})} \times 1000
$$


The concentrations of potassium, sodium, nitrate, calcium and magnesium were determined with a flame photometer (Keison Products) following [32] and [33].

\subsection{Microbial Analysis}

The total and faecal coliform content in the water samples were determined using the Most Probable Number (MPN) method of microbial analysis. Serial dilutions of $10-1$ to $10-6$ were prepared by packing $1 \mathrm{ml}$ of the sample into $9 \mathrm{ml}$ sterile distilled water. One millilitre aliquots from each of the dilutions were inoculated into $5 \mathrm{ml}$ of MacConkey Broth (Oxoid, Thermo Fisher Scientific Inc., $\mathrm{UK}$ ) incubated at $35^{\circ} \mathrm{C}$ for total coliforms and $44^{\circ} \mathrm{C}$ faecal coliforms for $18-24$ hours. At the end of the incubation, the samples were observed and the tubes showing colour change from purple to yellow after the 24 hours incubation were identified as positive for both total and faecal coliforms. Counts per $100 \mathrm{ml}$ were calculated from the Most Probable Number (MPN) table.

\subsection{Data Analysis}

After the physical and chemical properties and the microbial load of the twelve water samples collected at each of the five sampling points along the river were determined as explained above, the data obtained was subjected to analysis of variance (Minitab version 17; Minitab Inc., State College, PA) to determine statistical differences in the physico-chemical properties and microbial load at each section. Where significant differences were observed, the analysis was followed by Tukey's test (Minitab).

\section{Results}

Analysis of the physico-chemical properties of water samples from SU1, SU2, SU3, SU4 and SU5 showed very high significant differences in the means of total hardness $(\mathrm{F}=17.11$, d.f $=4, \mathrm{P}<0.001)$, calcium ion concentration $(\mathrm{F}=$ 10.51, d.f $=4, \mathrm{P}<0.001)$, total dissolved solids $(\mathrm{F}=9.20$, d.f $=4, \mathrm{P}<0.001)$, PO43- $(\mathrm{F}=10.05$, d.f $=4, \mathrm{P}<0.001), \mathrm{Mg}^{2+}(\mathrm{F}=19.17$, d.f $=4, \mathrm{P}<0.001)$, concentration of $\mathrm{Na}^{+}(\mathrm{F}=20.50$, d.f $<4, \mathrm{P}<0.001)$ and $\mathrm{pH}(\mathrm{F}=9.04$, d.f $=4, \mathrm{P}<$ 0.001 ) (Table 1). There were significant differences also in Turbidity $(\mathrm{F}=2.77$, d.f $=4, \mathrm{P}=0036)$, and $\mathrm{NO}_{3}^{-}(\mathrm{F}=3.28$, d.f $=4, \mathrm{P}=0.018)$. However, there was no significant difference in the mean concentration of $\mathrm{K}^{+}(\mathrm{F}=1.33$, d.f $=4, \mathrm{P}=$ 0.269 ) at the five sampling points of the river.

The total coliform of SU1 ranged from $0.03 \times 106$ to $45.00 \times 106 \mathrm{mpn} / 100 \mathrm{ml}$ of water $(n=10)$ with a mean total coliform of $22.97 \times 106 \pm 5.70 \times 106$ and median of $27.05 \times 106 \mathrm{mpn} / 100 \mathrm{ml}$ of water. The total coliform of SU2 ranged from $0.02 \times 106$ to $27.50 \times 106 \mathrm{mpn} / 100 \mathrm{ml}$ of water $(\mathrm{n}=10)$ with a mean total coliform of $13.05 \times 106 \pm 3.69 \times 106$ and median of $8.90 \times 106 \mathrm{mpn} / 100 \mathrm{ml}$ of water. At SU3 the total coliform ranged from $2.55 \times 106$ to $89.00 \times 106 \mathrm{mpn} / 100$ $\mathrm{ml}$ of water $(\mathrm{n}=10)$ with a mean total coliform of $16.28 \times 106 \pm 8.8 \times 106$ and median of $5.13 \times 106 \mathrm{mpn} / 100 \mathrm{ml}$ of water. The total coliform of SU4 ranged 
Table 1. Mean values of physical and chemical properties of water sampled at five sections of the Sumampa River namely SU1, SU2, SU3, SU4 and SU5.

\begin{tabular}{|c|c|c|c|c|c|c|c|c|c|c|}
\hline Sampling point & $\begin{array}{l}\text { Total Hardness } \\
(\mathrm{mg} / \mathrm{l})\end{array}$ & $\begin{array}{l}\mathrm{Ca}^{2+} \\
(\mathrm{mg} / \mathrm{l})\end{array}$ & $\begin{array}{l}\text { Turbidity } \\
\text { (NTU) }\end{array}$ & $\begin{array}{l}\text { TDS } \\
(\mathrm{mg} / \mathrm{l})\end{array}$ & $\begin{array}{c}\mathrm{NO}_{3}^{-} \\
(\mathrm{mg} / \mathrm{l})\end{array}$ & $\begin{array}{l}\mathrm{PO}_{4}^{3-} \\
(\mathrm{mg} / \mathrm{l})\end{array}$ & $\begin{array}{l}\mathrm{Mg}^{2+} \\
(\mathrm{mg} / \mathrm{l})\end{array}$ & $\begin{array}{c}\mathrm{K}^{+} \\
(\mathrm{mg} / \mathrm{l})\end{array}$ & $\begin{array}{l}\mathrm{Na}^{+} \\
(\mathrm{mg} / \mathrm{l})\end{array}$ & $\mathrm{pH}$ \\
\hline SU1 & 48 & 6.6 & 3.1 & 77 & 0.09 & 9.8 & 1 & 1.8 & 6.8 & 7.1 \\
\hline SU2 & 20 & 8.2 & 4.2 & 69.2 & 0.08 & 10.7 & 0.3 & 1.0 & 5.1 & 7.1 \\
\hline SU3 & 48 & 9.2 & 3.8 & 65.3 & 0.06 & 7.1 & 0.9 & 1.8 & 7.4 & 6.8 \\
\hline SU4 & 49 & 13.3 & 1.4 & 53.3 & 0.09 & 10.1 & 0.9 & 1.6 & 5.7 & 6.5 \\
\hline SU5 & 25 & 13.5 & 1.7 & 56.7 & 0.06 & 12.2 & 0.3 & 1.6 & 4.7 & 6.7 \\
\hline Mean & 38 & 10.15 & 2.8 & 64.3 & 0.08 & 9.98 & 0.7 & 1.6 & 6 & 6.8 \\
\hline $\operatorname{LSD}(\mathrm{P} \leq 0.05)$ & $<0.001$ & $<0.001$ & 0.036 & $<0.001$ & 0.018 & $<0.001$ & $<0.001$ & 0.269 & $<0.001$ & $<0.001$ \\
\hline $\begin{array}{l}\text { Acceptable } \\
\text { limits }\end{array}$ & & & & $1000^{\dagger *}$ & $50^{\dagger}$ & & & & & $6.5-8.5^{\dagger x}$ \\
\hline
\end{tabular}

NTU, Nephelometric Turbidity Unit; TDS, Total Dissolved Solids; WHO, World Health Organisation; EPA, Environmental Protection Agency of the United States of America. ${ }^{\dagger}$ Acceptable value by WHO standards; ${ }^{*}$ Acceptable value by EPA standard.

from $3.40 \times 106$ to $45.00 \times 106 \mathrm{mpn} / 100 \mathrm{ml}$ of water $(\mathrm{n}=10)$ with a mean total coliform of $16.65 \times 106 \pm 4.62 \times 106$ and median of $11.95 \times 106 \mathrm{mpn} / 100 \mathrm{ml}$ of water. The total coliform of SU5 ranged from $3.40 \times 106$ to $45.00 \times 106 \mathrm{mpn} / 100$ $\mathrm{ml}$ of water $(\mathrm{n}=10)$ with a mean total coliform of $16.13 \times 106 \pm 5.44 \times 106$ and median of $5.03 \times 106 \mathrm{mpn} / 100 \mathrm{ml}$ of water (Figure $1(\mathrm{a})$ ).

The feacal coliform of SU1 ranged from $0.73 \times 106$ to $4.50 \times 106(\mathrm{n}=7)$ $\mathrm{mpn} / 100 \mathrm{ml}$ of water with a mean value of $3.40 \times 106 \pm 0.53 \times 106 \mathrm{mpn} / 100 \mathrm{ml}$ of water and the median was $4.05 \times 106 \mathrm{mpn} / 100 \mathrm{ml}$ of water. The feacal coliform load in SU2 ranged from $0.89 \times 106$ to $4.5 \times 106(\mathrm{n}=7) \mathrm{mpn} / 100 \mathrm{ml}$ of water. The mean feacal coliform was $3.42 \times 106 \pm 0.56 \times 106 \mathrm{mpn} / 100 \mathrm{ml}$ of water and a median of $4.05 \times 106 \mathrm{mpn} / 100 \mathrm{ml}$ of water. The sampling point SU3 had a feacal coliform load ranging from $0.06 \times 106$ to $4.50 \times 106(\mathrm{n}=8)$ $\mathrm{mpn} / 100 \mathrm{ml}$ of water and a mean feacal coliform of $2.52 \times 106 \pm 0.62 \times 106$ $\mathrm{mpn} / 100 \mathrm{ml}$ of water and a median value of $2.55 \times 106$. The feacal coliform of SU4 ranged from $0.45 \times 106$ to $8.90 \times 106(\mathrm{n}=8) \mathrm{mpn} / 100 \mathrm{ml}$ of water. The mean feacal coliform was $3.61 \times 106 \pm 1.24 \times 106 \mathrm{mpn} / 100 \mathrm{ml}$ of water and the median was $2.75 \times 106 \mathrm{mpn} / 100 \mathrm{ml}$ of water. The feacal coliform of SU5 ranged from $0.024 \times 106$ to $23.50 \times 106(\mathrm{n}=8) \mathrm{mpn} / 100 \mathrm{ml}$ of water. The mean feacal coliform was $5.14 \times 106 \pm 2.68 \times 106 \mathrm{mpn} / 100 \mathrm{ml}$ of water and the median was $2.75 \times 106 \mathrm{mpn} / 100 \mathrm{ml}$ of water (Figure $1(\mathrm{~b})$ ). There were no significant differences in both the total coliforms $(\mathrm{F}=0.37$, d.f $=4, \mathrm{P}=0.826)$ and faecal $(\mathrm{F}=$ 0.45 , d.f $=4, P=0.775$ ) at the five respective areas of sample collection.

\section{Discussion}

A good quality drinking water should be clean, colourless and devoid of all forms of pollutants [34] [35] [36] but the same cannot be said of Sumampa River. Findings from our study indicate that the total hardness along the Sumampa 


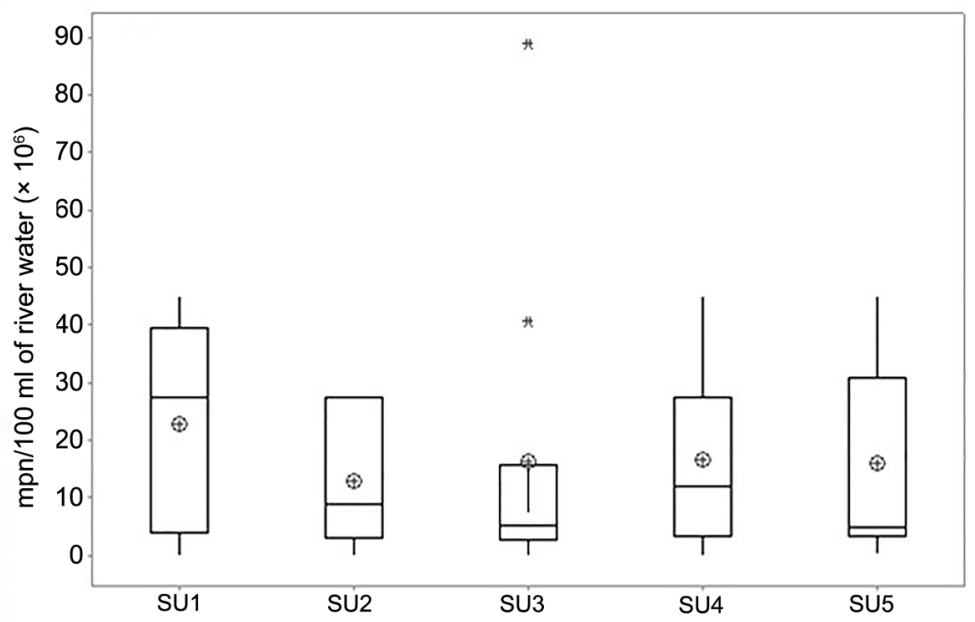

(a)

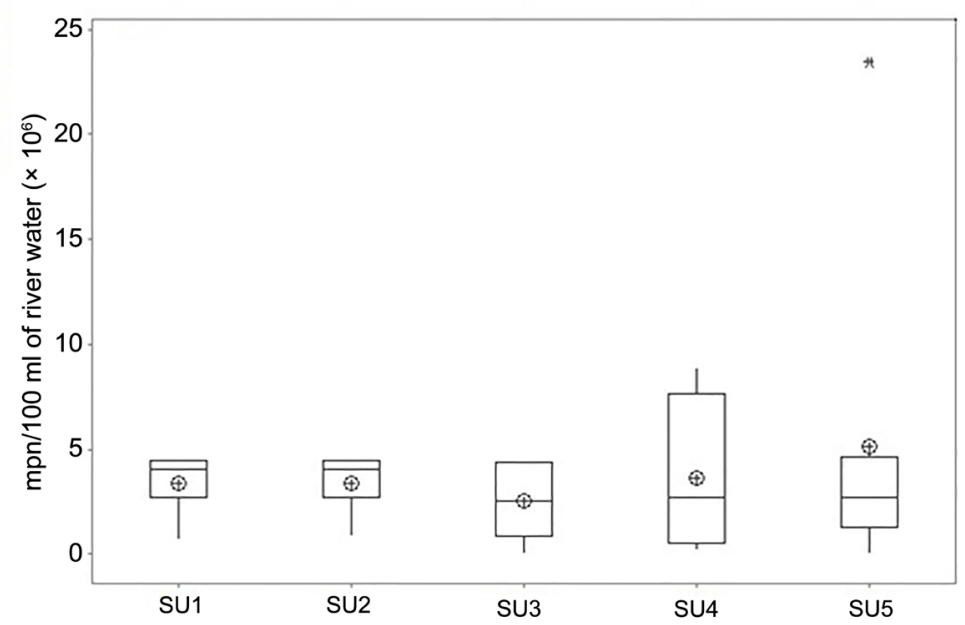

(b)

Figure 1. Total coliform (a) and faecal coliform (b) of Sumampa River.

River was significantly high. Particularly, water at SU4 and SU3 were consistently harder than water at the other sampling point. This observation is not surprising because, SU4 and SU3 had high $\mathrm{Ca}^{2+}$ and $\mathrm{Mg}^{2+}$ concentrations. It is known that high concentrations of $\mathrm{Ca}^{2+}$ and $\mathrm{Mg}^{2+}$ contribute to hardness of water [37]. Indeed, there were a lot of human settlements at the catchment and buffer zones of the river at SU3 which results in the influx of household wastewater into the river. At SU4, there was farming along the banks of the river and so agrochemicals might have leached into the river and polluted it.

The number of households around SU3 also affected the turbidity of the water at that point. Increase in waste materials in the water increased the turbidity. The turbidity of SU2 was highest probably because of continuous disturbance of the water by children who play in it. The point was also with a lot of physical pollutants from the community. In fact, a number of households have their drains directed into the water body at this point. SU1 had a relatively high turbidity because households close to that point fetch water there but they have to 
step in the water before fetching, thereby disturbing the water and making it turbid. Moreover, water tanker drivers draw water from SU1 for sale and vegetable farmers close by also pump water from this part of the water body to water their crops. These activities contribute to the turbidity of the water. Although SU4 was the hardest of water from all the sampling points, it was less turbid because there was minimum disturbance to the water at that point and anthropogenic activities were almost zero. It is worth noting that turbidity was below the acceptable limit set by Canada for drinking water ( 5 NTU) at all sampling points, but higher than 1NTU which is the USA standard for drinking water [38]. However, since there was some amount of turbidity recorded, it implies that there could be some pollutants and microbial load in the water [39] [40].

As expected, areas with high turbidity had high total dissolved solids. SU2, SU4 and SU1 had the highest turbidity as well as the highest total dissolved solids. These are strongly linked to the anthropogenic activities that go on in these areas. There is therefore the need to take measures that would reduce activities that impact negatively on the river. To make the community spearhead and own the responsibility of keeping the river clean, the Municipal assembly and the traditional authorities could initiate activities that will be supported by the whole community to help reduce pollution or bring it to a drastic minimum to save people from any form of disease especially those that take the untreated water home for domestic activities and drinking. A clean and good quality Sumampa is very important because it is one of the major sources of domestic water for the people of Mampong and its environs.

The mean phosphate value of $0.05 \mathrm{mg} / \mathrm{l}$ detected was relatively high. This suggests that farmers and households along the riverbank from upstream to downstream may have been using N-P-K fertilizer which likely leaches into the water especially during rainy seasons. The phosphate level in the water is especially high at SU5 which has vegetable farms at the banks which slopes down towards the river. Activities of farmers such as irrigation, fertilizer, pesticide and herbicide application likely increase pollutant levels in the water. In spite of the pollutants in the water, the mean $\mathrm{pH}$ at the various sampling points along the river were within the acceptable pH limits of 6.5 - 8.5 set by the EPA and WHO [41].

There were variable microbial loads along the river which suggests that activities that result in pollution were variable along the river. Indeed, open drains were channeled into the river at some points and these contributed to the variability of microbial load along the river. The microbial load at each of the sampling points was dependent on the period of sample collection and the activity carried out at that particular part of the river.

\section{Conclusion}

This study investigated the effect of anthropogenic activity on the quality of the Sumampa River. To do this, water samples were collected at various section of the river and their physico-chemical properties and microbial load were analysed. The analysis indicated that, sections of the river near settlements were 
highly turbid. We could therefore infer that where human settlements were high along Sumampa River, anthropogenic activities affecting the river were high and these resulted in high turbidity and high total dissolved solids. High anthropogenic activities come with pollution. It is therefore incumbent on the municipal assembly to put measures in place to protect the Sumampa River by creating a buffer zone for it through tree planting along the banks of the river. The trees could help detoxify the run-off water that flow into the river from the buffer zone. Aside detoxification of the river, a buffer zone will protect the river from human activities that have the potential to impact negatively on it. The resultant effect will be reduction of pollution levels in the water. We therefore recommend that, the municipal assembly liaise with the water company to educate communities along the river on the importance of a buffer zone to the river and emphasize the potential dangers associated with destructions of the river to the populace.

\section{Acknowledgements}

We wish to express our profound gratitude to the Chemistry and Microbiology laboratories at Kwame Nkrumah University of Science and Technology (KNUST) for providing space for the physico-chemical and microbial analysis.

\section{References}

[1] Ademe, A.S. and Alemayehu, M. (2014) Source and Determinants of Water Pollution in Ethiopia: Distributed Lag Modelling Approach. Intellectual Property Rights, 2, 1-6. https://doi.org/10.4172/2375-4516.1000110

[2] Gichana, Z.M., Njiru, M., Raburu, P.O. and Masese, F.O. (2014) Effects of Human Activities on Microbial Water Quality in Nyangores Stream, Mara River Basin. International Journal of Scientific \& Technology Research, 3, 153-157.

[3] Ayobahan, S.U., Ezenwa, I.M., Orogun, E.E., Uriri, J.E. and Wemimo, I.J. (2014) Assessment of Anthropogenic Activities on Water Quality of Benin River. Journal of Applied Science and Environmental Management, 18, 629-636.

[4] Agrawa, A., Pandey, R.S. and Sharma, B. (2010) Water Pollution with Special Reference to Pesticide Contamination in India. Journal of Water Resource and Protection, 2, 432-448. https://doi.org/10.4236/jwarp.2010.25050

[5] Firozia, N.J. and Sanal, K.M.G. (2013) Water Quality Assessment of Pamba River of Kerala, India in Relation to Pilgrimage Season. International Journal of Research in Chemistry and Environment, 3, 341-347.

[6] Fadaei, A. and Sadeghi, M. (2014) Evaluation and Assessment of Drinking Water Quality in Shahrekord, Iran. Resources and Environment, 4, 168-172.

[7] Jadoon, W.A., Arshad, M. and Ullah, I. (2012) Spatio-Temporal Microbial Water Quality Assessment of Selected Natural Streams of Islamabad, Pakistan. Records Zoological Survey of Pakistan, 21, 14-18.

[8] Rashid, I., Farooq, M., Muslim, M. and Romshoo, S.A. (2013) Assessing the Impact of Anthropogenic Activities on Manasbal Lake in Kashmir Himalayas. International Journal of Environmental Sciences, 3, 2036-2047.

[9] Kuhlmann, M.L., Imbimbo, H.R.V., Ogura1, L.L., Villani, J.P., Starzynski, R. and Maria de Jesus, R. (2014) Effects of Human Activities on Rivers Located in Pro- 
tected Areas of the Atlantic Forest. Acta Limnologica Brasiliensia, 26, 60-72. https://doi.org/10.1590/S2179-975X2014000100008

[10] Hou, F., Li, F. and Zhou, Q. (2015) Impact of Modern Human Activities on the Songhua River's Health in Heilongjiang Province. Management Science and Engineering, 9, 8-13.

[11] Omokhua, G.E. and Koyejo, A.O. (2008) Impact of Human Activities on Ecosystem in River State, Nigeria. Journal of Agriculture and Social Research, 8, 174-178.

[12] Owa, F.W. (2014) Water Pollution: Sources, Effects, Control and Management. International Letters of Natural Sciences, 8, 1-6. https://doi.org/10.18052/www.scipress.com/ILNS.8.1

[13] Masere, T.P., Munodawafa, A. and Chitata, T. (2012) Assessment of Human Impact on Water Quality along Manyame River. International Journal of Development and Sustainability, 1, 754-765.

[14] Erhunmwunse, N.O., Dirisu, A.R. and Ogbeibu A.E. (2013) Managing Eutrophication in Nigeria Inland waters. Journal of Water Resource and Protection, 5, 743-746.

[15] Akpor, O.B. and Muchie, M. (2011) Review: Environmental and Public Health Implications of Wastewater Quality. African Journal of Biotechnology, 10, 2379-2387.

[16] Chislock, M.F., Doster, E., Zitomer, R.A. and Wilson, A.E. (2013) Eutrophication: Causes, Consequences, and Controls in Aquatic Ecosystems. Nature Education Knowledge, 4, 1-8.

[17] Abdul-Razak, A., Asiedu, A.B., Entsua-Mensah, R.E.M. and de Graft-Johnson, K.A.A. (2009) Assessment of the Water Quality of the Oti River in Ghana. West African Journal of Applied Ecology, 15, 1-12.

[18] Sleem S.H. and Hassan M.M. (2010) Impact of Pollution on Invertebrates Biodiversity in the River Nile. International Journal of Environmental Science and Engineering, 1, 15-25.

[19] Anhwange, B.A., Agbaji, E.B. and Gimba E.C. (2012) Impact Assessment of Human Activities and Seasonal Variation on River Benue, within Makurdi Metropolis. International Journal of Science and Technology, 2, 248-254.

[20] Akan, J.C., Abbagambo, M.T., Chellube, Z.M. and Abdulrahman, F.I. (2012) Assessment of Pollutants in Water and Sediment Samples in Lake Chad, Baga, North Eastern Nigeria. Journal of Environmental Protection, 3, 1428-1441. https://doi.org/10.4236/jep.2012.311161

[21] Ishaq F. and Khan, A. (2013) Seasonal Limnological Variation and Macro Benthic Diversity of River Yamunaat Kalsi Dehradun of Uttarakhand. Asian Journal of Plant Science and Research, 3, 133-144

[22] Lokhande1, S.R., Singare, P.U. and Pimple, D.S. (2011) Study on Physico-Chemical Parameters of Waste Water Effluents from Taloja Industrial Area of Mumbai, India. International Journal of Ecosystem, 1, 1-9. https://doi.org/10.5923/j.ije.20110101.01

[23] Okumagba, P.O. and Ozabor, F. (2014) The Effects of Socio-Economic Activities on River Ethiope. Journal of Sustainable Society, 3, 1-6. https://doi.org/10.11634/216825851403528

[24] Halder, J.N. and Islam, M.N. (2015) Water Pollution and Its Impact on the Human Health. Journal of Environment and Human, 2, 36-46. https://doi.org/10.15764/EH.2015.01005

[25] Garba, A.D. (2014) Impact of Anthropogenic Activities on the Quality of Water Resources in Kaduna Metropolis, Nigeria. The International Journal of Engineering and Science, 3, 16-21. 
[26] Páll, E., Niculae, M., Timea K., Şandru, C.D. and Spînu, M. (2013) Human Impact on the Microbiological Water Quality of the Rivers: Review. Journal of Medical Microbiology, 62, 1635-1640. https://doi.org/10.1099/jmm.0.055749-0

[27] Ezekwe, I.C., Ezekwe, A.S. and Endoro, O.P. (2013) Biological Contaminants in the River Nun and Environmental Ethics of Riverside Communities in the Niger Delta: The Case of Amassoma, Bayelsa, Nigeria. Estudos de Biologia, 35, 67-75.

[28] Agboola, J.I. and Denloye, A.A.B. (2011) Preliminary Assessment of Anthropogenic Impact on Some Ecological Components of Abesan River, Lagos, Nigeria. Journal of Water Resource and Protection, 3, 98-104. https://doi.org/10.4236/jwarp.2011.32011

[29] Sarkodie, P.A., Agyapong, D., Larbi, G.O. and Owusu-Ansah, E. (2014) A Comparative Study of the Quality of Wastewater from Tema Oil Refinery (TOR) against EPA Standards and Its Effect on the Environment. Civil and Environmental Research, 6, 85-91.

[30] Masese, F.O., Raburu, P.O., Mwasi, B.N. and Etiégni, L. (2012) Effects of Deforestationon Water Resources: Integrating Science and Community Perspectives in the Sondu-Miriu River Basin, Kenya. In: Oteng-Amoako, A.A., Ed., New Advances and Contributions to Forestry Research, InTech, Rijeka. 268 p, 1-18. http://cdn.intechopen.com/pdfs-wm/35539.pdf

[31] Betz, J.D. and Noll, C.A. (1950) Total-Hardness Determination by Direct Colorimetric Titration. Journal of the American Water Works Association, 42, 49-56.

[32] Hald, P.M. (1947) The Flame Photometer for the Measurement Sodium and Potassium in Biological Materials. The Journal of Biological Chemistry, 167, 499-510.

[33] Amrutkar, R.D, Thube, A.E. and Kulkarni, S.C. (2013) Determination of Sodium and Potassium Content Present in Water Sample Collected from Girna and Godavari River by Flamephotometry. Journal of Pharmaceutical Science and Bioscientific Research, 3, 105-107.

[34] Krenkel, P.A. and Novotny, V. (2016) Water Quality Management. Academic Press Inc., New York, 671.

[35] Kot-Wasik, A. (2016) Water for Different Purposes. In: Kot-Wasik, A., Water Quality Control, Faculty of Chemistry Gdańsk University of Technology, Gdansk, Poland, 184-218. http://www.pg.gda.pl/chem/Dydaktyka/Analityczna/WQC/wqc_p4.pdf

[36] Tamungang, N.E.B., Alakeh, M.N., Niba, M.L.F. and Jude, S. (2016) Physico-Chemical and Bacteriological Quality Assessment of the Bambui Community Drinking Water in the North West Region of Cameroon. African Journal of Environmental Science and Technology, 10, 181-191.

[37] Johnson, R.L., Redding, K. and Holmquist, D.D. (2007) Water Quality with Vernier. Vernier Software and Technology, Beaverton.

[38] Dessie, A. and Bredemeier, M. (2013) The Effect of Deforestation on Water Quality: A Case Study in Cienda Micro Watershed, Leyte, Philippines. Resources and Environment, 3, 1-9.

[39] Shittu, O.B., Olaitan, J.O. and Amusa, T.S. (2008) Physico-Chemical and Bacteriological Analyses of Water Used for Drinking and Swimming Purposes in Abeokuta, Nigeria. African Journal of Biomedical Research, 11, 285-290.

[40] Ojo, O.I., Otieno, F.A.O. and Ochieng, G.M. (2012) Groundwater: Characteristics, Qualities, Pollutions and Treatments: An Overview. International Journal of Water Resources and Environmental Engineering, 4, 162-170.

[41] Thompson, T., Fawell, J., Kunikane, S., Jackson, D., Appleyard, S., Callan, P., Bar- 
tram, J. and Kingston, P. (2007) Chemical Safety of Drinking-Water: Assessing Priorities for Risk Management. World Health Organisation Library Cataloguingin-Publication Data.

Submit or recommend next manuscript to SCIRP and we will provide best service for you:

Accepting pre-submission inquiries through Email, Facebook, LinkedIn, Twitter, etc. A wide selection of journals (inclusive of 9 subjects, more than 200 journals)

Providing 24-hour high-quality service

User-friendly online submission system

Fair and swift peer-review system

Efficient typesetting and proofreading procedure

Display of the result of downloads and visits, as well as the number of cited articles

Maximum dissemination of your research work

Submit your manuscript at: http://papersubmission.scirp.org/

Or contact jwarp@scirp.org 